\title{
Functional expression of opioid receptor-like receptor and its endogenous specific agonist nociceptin/orphanin FQ during mouse embryogenesis
}

WU Ya LAN, GuO HuAng FAN, JiAn ZHAO, Yi ZHANG, TIAN HUA ZHOU, LAN MA*, GANG PEI ${ }^{1}$

Shanghai Institute of Cell Biology, Chinese Academy of Sciences, Shanghai 200031, China

* Shanghai Medical University, Shanghai 200032, China

\begin{abstract}
Expression of opioid receptor-like receptor $\left(\mathrm{ORL}_{1}\right)$ and its endogenous peptide agonist nociceptin/orphanin FQ (N/OFQ) during mouse embryogenesis have been investigated. Transcripts of $\mathrm{ORL}_{1}$ and N/OFQ were detected by RT-PCR in mouse brain of day 8 embryo (E8) and the expression continued afterwards. Northern blot analysis revealed abundant expression of $\mathrm{ORL}_{1}$ at postnatal day 1 (P1) and N/OFQ at E17 and P1 in the brain but none was detected in other embryonic tissues. The presence of functional $\mathrm{ORL}_{1}$ in mouse embryonic brain was also confirmed by specific binding of $\left[{ }^{3} \mathrm{H}\right] \mathrm{N} / \mathrm{OFQ}(\mathrm{kd}=1.3$ $\pm 0.5 \mathrm{n} M$ and Bmax $=72 \pm 9 \mathrm{fmol} / \mathrm{mg}$ protein) as well as by $\mathrm{N} / \mathrm{OFQ}$-stimulated $\mathrm{G}$ protein activation.
\end{abstract}

Key words: Opioid receptor-like receptor $\left(O R L_{1}\right)$, nociceptin/orphanin $F Q(N / O F Q)$, mouse embryogenesis, functional expression.

\section{INTRODUCTION}

Opioid receptors belong to the G-protein-coupled receptor family that is characterized by the seven transmembrane spanning domains in structure. Three subtypes of the opioid receptors $(\mu, \delta$, and $\kappa$ ) have been cloned and characterized through their

1. Corresponding author 
Functional expression of $\mathrm{ORL}_{1}$ and $\mathrm{N} / \mathrm{OFQ}$ during mouse embryogenesis

distinct affinities for different opioid ligands. These opioid receptors are all coupled to the inhibitory $\mathrm{G}$ protein $(\mathrm{Gi})$ and negatively regulate adenylate cyclase[1]. Opioid receptor-like receptor $\left(\mathrm{ORL}_{1}\right)$, a new member of this family of G-protein coupled receptors, has been cloned from brain recently, which shares high homology in sequence with other opioid receptors[2-8]. ORL 1 binds to previously identified opioid peptides with poor affinity, and its endogenous specific agonist nociceptin/orphanin FQ $(\mathrm{N} / \mathrm{OFQ})$ has just been identified[9, 10]. Data from our and other laboratories have demonstrated that in neuronal cells, N/OFQ inhibits forskolin-stimulated cAMP accumulation, stimulates activation of pertussis toxin-sensitive G proteins[11-13], and increases inwardly rectifying $\mathrm{K}^{+}$conductance[14]. Behavioral studies demonstrate that $\mathrm{N} / \mathrm{OFQ}$, unlike other opioids, produces hyperalgesic effect[10] and even functionally antagonizes the antinociceptive effect of other opioids[15, 16]. It was lately found that $\mathrm{ORL}_{1}$-knock-out mice display hearing impairment[17]. However, information on the expression of $\mathrm{ORL}_{1}$ and $\mathrm{N} / \mathrm{OFQ}$ during mouse embryonic development is lacking. In the present study, we have demonstrated that both $\mathrm{ORL}_{1}$ and $\mathrm{N} / \mathrm{OFQ}$ express in mouse embryonic brain but not in other tissues and that N/OFQ stimulation leads to activation of inhibitory $\mathrm{G}$ proteins.

\section{MATERIALS AND METHODS}

\section{Animals}

Pregnant female Balb/c mice on embryonic days 8, 10, 14, 17, 19 (E8, E10, E14, E17, E19), postnatal day 1 (P1) mice and adult mice were obtained from the Animal House of Shanghai Institute of Cell Biology. All animals were sacrificed with the use of cervical dislocation following the Guideline for the Care and Use of Animals approved by the Institute.

\section{Isolation of total RNA}

50-100 mg of tissue was homogenized in $1 \mathrm{ml}$ of TRIzol Reagent (Gibco-BRL) using a glass homogenizer. Total RNA was extracted according to the manufacturer-provided protocols and dissolved in diethypyrocarbonate (DEPC) treated water. The amount of total RNA was determined by absorbence at $260 \mathrm{~nm}$.

\section{Reverse transcription polymerase chain reaction $(R T-P C R)$}

First-strand cDNA was made from total RNA by using Superscript preamplifiaction system (Gibco-BRL) and following the procedures suggested by the manufacturer. $2 \mu \mathrm{g}$ of total RNA and $0.5 \mu \mathrm{g}$ of oligo $(\mathrm{dT})_{12-18}$ was heated to $70{ }^{\circ} \mathrm{C}$ for $10 \mathrm{~min}$ in $11 \mu \mathrm{l}$ of DEPC-treated water. $4 \mu \mathrm{l}$ of 5 $\times$ synthesis buffer $\left(250 \mathrm{~m} M\right.$ Tris-HCl, pH 8.3, $375 \mathrm{~m} M \mathrm{KCl}, 15 \mathrm{~m} M \mathrm{MgCl}_{2}$ ), $1 \mathrm{ml}$ of $10 \mathrm{~m} M \mathrm{dNTP}$ mix, $2 \mu \mathrm{l}$ of $0.1 M$ DTT, $1 \mu \mathrm{l}$ of RNasin $(20 \mathrm{U} / \mu \mathrm{l})$ and $1 \mu \mathrm{l}$ of reverse transcriptase (SuperScript II $\mathrm{RT} ; 200 \mathrm{U} / \mu \mathrm{l}$ ) were added to the sample, and then incubated the samples at $42{ }^{\circ} \mathrm{C}$ for $1 \mathrm{~h}$. The reaction was terminated by incubating the mixture at $70{ }^{\circ} \mathrm{C}$ for $10 \mathrm{~min}[18]$.

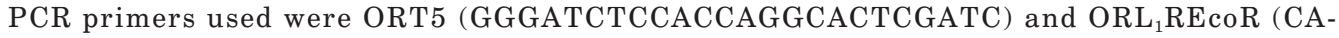
GGAATTCCATGGGCAGGTCCACGCCTAGTC) for ORL $\mathrm{O}_{1}$; OFQ5 (ACTGCCTCACCTGCCAGG) and OFQ3 (GGCTCCTTCTGGCTACAC) for N/OFQ. ORT5/ORL 1 REcoR primers correspond to regions from bases 497 to 515 and 1293 to 1310 on human $\mathrm{ORL}_{1}$ cDNA[2] respectively and are conserved among rat, mouse and human. OFQ5/OFQ3 primers were correspond to regions from bases 31 to 47 and 502 to 518 on rat N/OFQ precursor cDNA[9] respectively. The PCR reactions $(50 \mu \mathrm{l})$ contained $5 \mu \mathrm{l}$ of first-strand cDNA, 2 units of Taq polymerase (Promega). The condi- 
tions used were: $94{ }^{\circ} \mathrm{C}$ for $1 \mathrm{~min} ; 60{ }^{\circ} \mathrm{C}$ for $1 \mathrm{~min} ; 72{ }^{\circ} \mathrm{C}$ for $1.5 \mathrm{~min}$. This cycle was repeated 30 times. The PCR products ( $\sim 800 \mathrm{bp}$ and $480 \mathrm{bp}$ respectively) were analyzed on a $1 \%$ agarose gel.

\section{Northern blot analysis}

Total RNA of each sample was electrophoresed on a $1 \%$ agarose-glyoxal gel (30 $\mu \mathrm{g} / \mathrm{lane}$ except lane 1 was $10 \mu \mathrm{g})$, transferred onto a nylon membrane (Amersham) with $20 \times \operatorname{SSC}(1 \times \mathrm{SSC}$ is 0.15 $M$ Sodium Chloride, 0.15 $M$ Sodium Citrate, pH 7.0). Then the membrane was exposed to UV light using a GS Gene Linker (Bio-Rad).

The $1150 \mathrm{bp}$ restriction fragment containing entire coding region of $\mathrm{ORL}_{1}$ was released from plasmid pcDNA hORL $_{1}$ [18], purified using QIAEX Gel Extraction Kit (QIAEX), and used as $\mathrm{ORL}_{1}$ probe. N/OFQ probe was the $480 \mathrm{bp} \mathrm{PCR} \mathrm{product} \mathrm{of} \mathrm{OFQ5/OFQ3} \mathrm{purified} \mathrm{using} \mathrm{QIAEX}$ Gel Extraction Kit. ${ }^{32} \mathrm{P}$-labeled random-primed probes were made to a specific activity of $5 \times 10^{8}$ dpm/g DNA using the Ready To Go DNA Labeling Kit (Pharmacia Biotech).

The membrane was perhybridized in $0.5 M$ phosphate buffer (pH 7.2), 7 \% Sodium Dodecyl Sulfate (SDS), $1 \mathrm{mM}$ EDTA at $65{ }^{\circ} \mathrm{C}$ for $4 \mathrm{~h}$, and hybridized to ${ }^{32} \mathrm{P}$-labeled probe at $65{ }^{\circ} \mathrm{C}$ for $20 \mathrm{~h}[19]$. The membrane was washed twice in $2 \times \mathrm{SSC} / 0.1 \% \mathrm{SDS}$ at room temperature for 15 min each, and then twice in $0.5 \times \mathrm{SSC} / 0.1 \% \mathrm{SDS}$ at $55{ }^{\circ} \mathrm{C}$ for $15 \mathrm{~min}$ each. The membrane was exposed to X-ray film (Kodak) for 5-7 days.

\section{N/OFQ binding assay}

Mouse embryonic brain membranes were prepared by homogenizing the embryonic brain in 1 $\mathrm{ml}$ of lysis buffer containing $5 \mathrm{~m} M$ Tris-HCl (pH 7.5), $5 \mathrm{mM}$ EDTA, and $5 \mathrm{mM}$ EGTA and the membrane lysate was centrifuged at $3000 \times \mathrm{g}$ at $4{ }^{\circ} \mathrm{C}$ for $15 \mathrm{~min}$. Then the supernatant was centrifuged at $30,000 \times \mathrm{g}$ at $4{ }^{\circ} \mathrm{C}$ for $30 \mathrm{~min}$. Pellets were solubilized in buffer containing $50 \mathrm{~m} M$ Tris-HCl ( $\mathrm{pH} 7.5$ ), $5 \mathrm{~m} M$ EDTA, and $5 \mathrm{~m} M$ EGTA. The binding assay was carried out basically as described[11]. Aliquot with different concentrations $(2.0 \sim 11.0 \mathrm{n} M)$ of $\left[{ }^{3} \mathrm{H}\right] \mathrm{N} / \mathrm{OFQ}(39 \mathrm{Ci} / \mathrm{mmol}$, Phoenix Pharmaceuticals, Inc, CA) in a total volume of $0.2 \mathrm{ml}$ were incubated at $30{ }^{\circ} \mathrm{C}$ for $60 \mathrm{~min}$. The reaction was terminated by diluting with cold phosphate-buffered saline and filtered through glass fiber filters under vacuum. Bound radioactivity was measured by liquid scintillation counter (Beckmann Instruments, Torrance, CA). Nonspecific binding was measured in the presence of 100 $\mathrm{mM}$ etorphine (Sigma). Equilibrium binding data were analyzed using the curve- fitting program LIGAND. Protein content of each sample was determined as described above.

\section{$\left[{ }^{35} \mathrm{~S}\right]$ GTPS binding assay}

The assay was carried out as described[11, 20]. Embryonic brain membranes were prepared as above. The membrane (containing $12 \mu \mathrm{g}$ protein) in $50 \mathrm{mM}$ Tris- $\mathrm{HCl}$ (pH 7.5), $5 \mathrm{mM} \mathrm{MgCl}_{2}, 1 \mathrm{mM}$ DTT, $100 \mathrm{mM} \mathrm{NaCl}, 40 \mu \mathrm{M}$ GDP, and $0.5 \mathrm{nM}\left[{ }^{35} \mathrm{~S}\right] \mathrm{GTP}$ y $\mathrm{S}(1200 \mathrm{Ci} / \mathrm{mmol}$, DuPont-New England Nuclear) in the presence or absence of N/OFQ, [D-Ala ${ }^{2}, \mathrm{MePhe}^{4}, \mathrm{Gly}^{-o l^{5}}$ ] enkephalin (DAGO) (Sigma), or UK14304 (Sigma) in a total volume of $100 \mu \mathrm{l}$ were incubated at $30{ }^{\circ} \mathrm{C}$ for $60 \mathrm{~min}$. The reaction was terminated by adding $4 \mathrm{ml}$ phosphate-buffered saline and then immediately filtered through GF/C filters under vacuum. The filters were washed and counted by liquid scintillation counter. Data were means of duplicate samples. Basal binding was determined in the absence of agonist and non-specific binding was obtained in the presence of $10 \mathrm{mM}$ GTP $\gamma \mathrm{S}$. The percentage of stimulated $\left[{ }^{35} \mathrm{~S}\right] \mathrm{GTP}$ y $\mathrm{S}$ was calculated as $100 \times\left(\mathrm{cpm}_{\text {sample }}-\mathrm{cpm}_{\text {nonspecific }}\right) /\left(\mathrm{cpm}_{\text {basal }}-\right.$ $\operatorname{cpm}_{\text {non-specific }}$ ).

\section{RESULTS AND DISCUSSION}

\section{Expression of $O R L_{1}$ and $N / O F Q$ during development}

In situ hybridization and immunohistochemistry studies revealed that $\mathrm{ORL}_{1}$ and 
Functional expression of $\mathrm{ORL}_{1}$ and $\mathrm{N} / \mathrm{OFQ}$ during mouse embryogenesis

its endogenous ligand N/OFQ express widely over the brain[3, 4, 6, 9, 21, 22]. $\mathrm{ORL}_{1}$ transcripts are present in the CNS, including the hypothalamus, brainstem and spinal cord dorsal horn[1, 7,8]. ORL $\mathrm{O}_{1}$ also expresses in a few peripheral organs such as intestine, vas deferens and spleen[6]. It suggests that $\mathrm{ORL}_{1}$ plays a role in many central processes, including learning and memory. Transcripts of N/OFQ precursor protein was detected during mouse embryogenesis[23]. However, the expression of $\mathrm{ORL}_{1}$ in embryogenesis has not been reported. Therefore, we examined the expression of $\mathrm{ORL}_{1}$ and N/OFQ in mouse brains on various embryonic days (E8, E10, E14, E17, E19) and postnatal day 1 (P1) as well as in adult mouse brain. To detect $\mathrm{ORL}_{1}$ receptor mRNA sensitively, we measured the levels of $\mathrm{ORL}_{1}$ and N/OFQ transcripts with RT-PCR and Northern blotting. As shown in Fig $1 \mathrm{~A}$ and $\mathrm{B}$, with the primer sets of $\mathrm{ORT} 5 / \mathrm{ORL}_{1} \mathrm{REcoR}$ and $\mathrm{OFQ5/OFQ3,} \mathrm{PCR} \mathrm{products}$

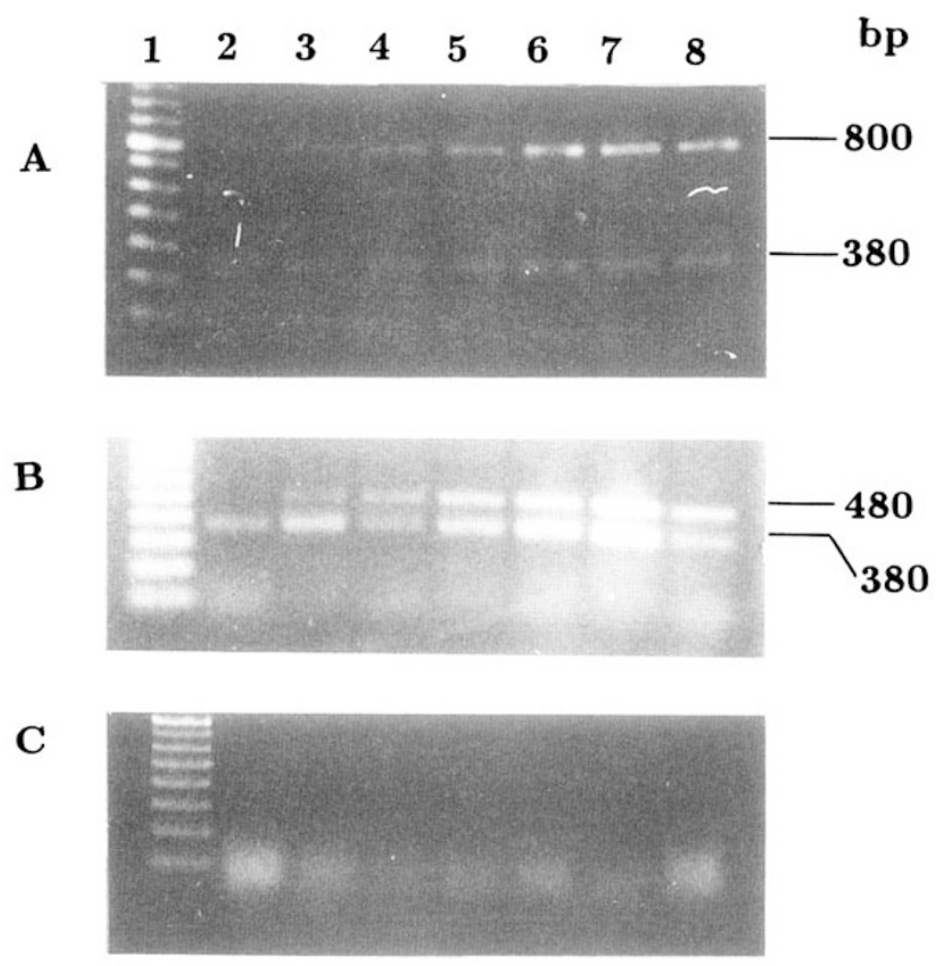

Fig 1. Embryonic expression of $\mathrm{ORL}_{1}$ and N/OFQ mRNA in mouse brain detected by RT-PCR. The expression was assayed by RT-PCR for $\mathrm{ORL}_{1}$ using primer pair of ORL5/ORL $\mathrm{OEE}_{1} \mathrm{R}(\mathrm{A})$ and for N/OFQ using primer pair of OFQ5/OFQ3 (B). As control, the total RNA was used as the PCR template without RT reaction, using primer pair of ORL5/ORL $\mathrm{REcoR}_{1}$ and OFQ5/OFQ3 (C). Internal controls of actin was included in each PCR reaction and the actin products were shown as a band of $380 \mathrm{bp}$. Lane 1: DNA markers, lane 2:E8 (0.3;0), lane 3: E10 (1.0;0.1), lane 4:E14 (2.7;0.9), lane 5:E17 (5.1;0.95), lane 6:E19 (9.8; $0.90)$, lane 7 : P1 $(9.9 ; 0.92)$, lane 8 : adult $(9.5 ; 1.1)$. In each lane, the amount of PCR product determined by densitometer relative to internal control $\beta$-actin was indicated in parentheses $(\mathrm{A} ; \mathrm{B})$. 
of expected sizes ( $800 \mathrm{bp}$ and $480 \mathrm{bp}$ ) were detected in brain samples from E10 to adult mice (Lanes 3-8). PCR reactions using embryonic brain RNA (without reverse transcription Fig 1C) and the cDNA form other embryonic tissues (kidney, liver, heart) as template failed to produce any detectable PCR product (data not shown). $\beta$-actin was used as a positive internal control in PCR $(\sim 380 \mathrm{bp})$. The quantitative densitometry analysis show from mouse E10 to E19, the amounts of RT-PCR products (relative to the product of $\beta$-actin used as an internal control) of $\mathrm{ORL}_{1}$ and $\mathrm{OFQ}$ increased and they maintained the similar levels since E19. The above results indicate that the transcripts for $\mathrm{ORL}_{1}$ and N/OFQ are present in embryonic, postnatal and adult mice brains.

In Northern analysis, $\mathrm{ORL}_{1}$ and N/OFQ transcripts were detected only in embryonic and postnatal mice brains, not in other embryonic and postnatal tissues. For $\mathrm{ORL}_{1}, \mathrm{P} 1$ brain contains a RNA species of $3.7 \mathrm{~kb}$, hybridizable to the $\mathrm{ORL}_{1}$ cDNA probe (Fig 2A, lane 3), but $\mathrm{ORL}_{1}$ transcripts were not detectable in E17 under the same conditions (Fig 2A, lane 2). For N/OFQ, a RNA species of $1.3 \mathrm{~kb}$ were detected (Fig 2B, lane 2, 3) in both E17 and P1 brain.

The results of RT-PCR and Northern analysis indicate that the transcripts of $\mathrm{ORL}_{1}$ and $\mathrm{N} / \mathrm{OFQ}$ are present on and after E10. Nothacker et al reported that the OFQ precursor mRNA was detected in fetal human brain and kidney but not in adult human kidney by Northern analysis[24]. In present study, the expression of OFQ did not been detected in mouse E17 and P1 kidney. This could be a result of the samples used in different species and/or different embryonic stages. In $\mu$ receptordeficient mice, some unexpected changes in sexual function in male homozygotes were observed, such as reduced mating activity, a decrease in sperm count and motility, and litter size[25]. These data suggest that opioid receptor may play an important role in development. Other reports confirmed that N/OFQ mRNA was detected in mouse brains of embryonic day 14, and larger amounts were detected on postnatal day 1 . Then the levels of mRNA decreased gradually as mouse grew[23].

Membrane fractions were prepared from E17 brain, and the presence of $\mathrm{ORL}_{1}$ receptors was examined using $\left[{ }^{3} \mathrm{H}\right] \mathrm{N} / \mathrm{OFQ}$, a specific agonist of $\mathrm{ORL}_{1}$. As shown in Fig 3A, binding of $\mathrm{N} / \mathrm{OFQ}$ to embryonic brain membranes was specific and saturable. Analysis of saturation binding data indicates a dissociation constant kd of $1.3 \pm 0.5 \mathrm{n} M$ and $\mathrm{B}_{\max }$ of $72 \pm 9 \mathrm{fmol} / \mathrm{mg}$ protein, comparable to the value obtained in rat brain homogenates[26] and in neuroblastoma cells[11, 13]. These data are consistent with our RT-PCR and Northern results and confirm that the gene product of $\mathrm{ORL}_{1}$ is expressed on cell membranes of embryonic brain.

\section{ORL $L_{1}$-mediated $G$ protein activation}

$\left[{ }^{35} \mathrm{~S}\right] \mathrm{GTP}-\gamma \mathrm{S}$ binding is an effective method to probe gonist-dependent activation of $\mathrm{G}$ proteins. Using this method, the activation of pertussis toxin (PTX)-sensitive $\mathrm{G}$ proteins after agonist occupation of opioid[27], muscarinic[28, 29], a 2-adrenergic 
Functional expression of $\mathrm{ORL}_{1}$ and N/OFQ during mouse embryogenesis
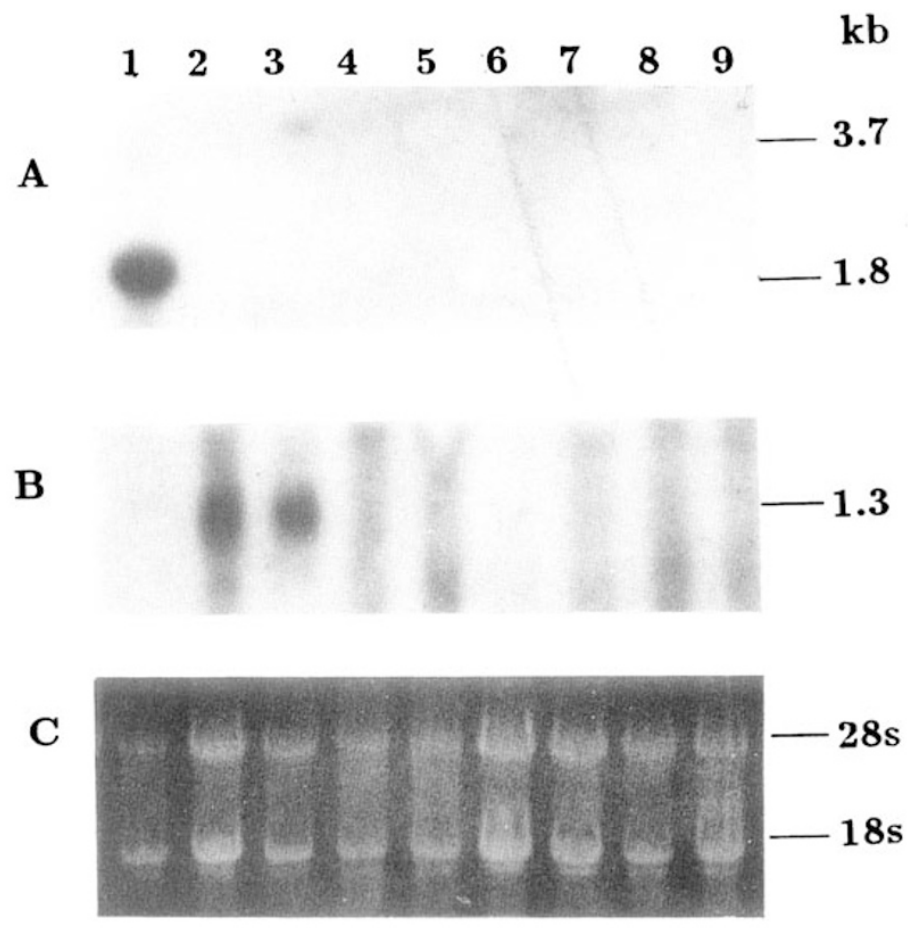

Fig 2. Northern analysis of $\mathrm{ORL}_{1}(\mathrm{~A})$ and $\mathrm{N} / \mathrm{OFQ}$ (B) mRNA transcripts. Lane 1:

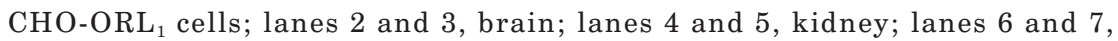
liver; lanes 8 and 9, heart. Lanes 2, 4, 6, 8: E17; lanes 3, 5, 7, 9: P1. (C) Ethidium bromide staining of the gel before Northern blotting.

plasma membrane-bound receptors have been determined[13]. We have observed that $\mathrm{ORL}_{1}$ receptor was expressed on mouse embryonic brain membranes. Therefore, we took on to determine the activation of the inhibitory G-protein mediated by $\mathrm{ORL}_{1}$ in embryonic brain using $\left[{ }^{35} \mathrm{~S}\right] \mathrm{GTP}$ r $\mathrm{S}$ binding. As shown in Fig 3B, activation of $\mu$ opioid receptor by DAGO and $\alpha 2$-adrenergic by UK14304 increased $\left[{ }^{35} \mathrm{~S}\right] \mathrm{GTP} \gamma \mathrm{S}$ binding $10-30 \%$, however, in strong contrast, stimulation of $10 \mathrm{~m} M \mathrm{~N} / \mathrm{OFQ}$ caused an $100 \%$ increase in $\left[{ }^{35} \mathrm{~S}\right] \mathrm{GTP}$ r $\mathrm{S}$ binding to the membranes from embryonic brain. These data confirm the expression of $\mathrm{ORL}_{1}$ in embryonic brain and indicate that $\mathrm{ORL}_{1}$ is functionally coupled to $\mathrm{G}$ protein. The results also suggest that $\mathrm{ORL}_{1}$ may be present in embryonic brain more abundant than $\mu$ opioid receptors, or alternatively, it may couple to $\mathrm{G}$ protein more efficiently than $\mu$ opioid receptor in fetal brain. Experimental data have shown that $\mathrm{ORL}_{1}$ and $\mu$ opioid receptor mediate opposite effects in pain modulation[9, 10]. Changes in sexual functions such 
as reduced mating activity, decreases in sperm count and motility, and litter size have been observed in male homozygotes of $\mu$ receptor-knock-out mice[25]. These results suggest that opioid receptor may play a role in development. The differential activities in $\mathrm{G}$ protein activation mediated by these two important receptors may therefore have developmental significance.
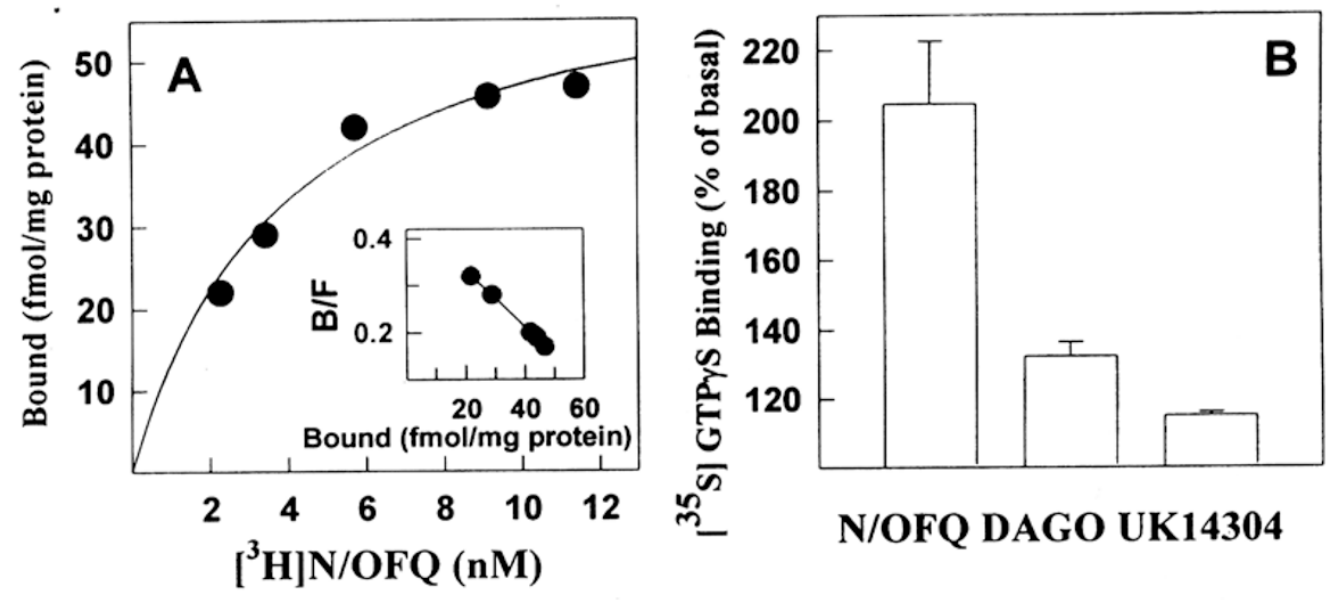

N/OFQ DAGO UK14304

Fig 3. Functional expression of $\mathrm{ORL}_{1}$ in mouse embryonic brain. (A) Saturation binding of $\left[{ }^{3} \mathrm{H}\right]$-labeled $\mathrm{N} / \mathrm{OFQ}$ to $\mathrm{ORL}_{1}$ receptor. The membrane preparations were incubated with various concentration of $\left[{ }^{3} \mathrm{H}\right] \mathrm{N} / \mathrm{OFQ}$ and the $\left[{ }^{3} \mathrm{H}\right] \mathrm{N} / \mathrm{OFQ}$ bound was determined. (B) $\left[{ }^{35} \mathrm{~S}\right] \mathrm{GTP}$ \% S binding assay: Assays were performed in the presence of $10 \mathrm{mM}$ N/OFQ, $10 \mu M$ DAGO, or $10 \mu M$ UK14304 respectively, at $30{ }^{\circ} \mathrm{C}$ for $60 \mathrm{~min}$. Data were means \pm standard error of two independent experiments performed in duplicate.

In summary, we have demonstrated that $\mathrm{ORL}_{1}$ and $\mathrm{N} / \mathrm{OFQ}$ is functionally expressed in mouse embryonic brain. RT-RCR and Northern analysis indicate the presence of $\mathrm{ORL}_{1}$ and N/OFQ transcripts in mouse embryonic brain. $\left[{ }^{3} \mathrm{H}\right] \mathrm{N} / \mathrm{OFQ}$ bound to the embryonic brain membranes specifically. Binding of the receptor with its specific agonist N/OFQ activated inhibitory $\mathrm{G}$ protein as indicated by stimulation of $\left[{ }^{35} \mathrm{~S}\right] \mathrm{GTP}$ \& $\mathrm{S}$ binding.

\section{ACKNOWLEDGMENTS}

This research was supported by research grants from National Natural Science Foundation of China (39630130 and 39625010), Chinese Academy of Sciences (KY951A1-301-01-05), Shanghai Educational Development Foundation, and the German Max-Planck Society. The authors thank Yan Ping WANG and Ping WANG for their help. 


\section{Functional expression of $\mathrm{ORL}_{1}$ and $\mathrm{N} / \mathrm{OFQ}$ during mouse embryogenesis}

\section{REFERENCES}

[1] Reisine T. Opiate receptors. Neuropharmacology 1995; 34:463-72.

[2] Mollereau C, Parmentier M, Mailleux P. et al. ORL $\mathrm{O}_{1}$, a novel member of the opioid receptor family Cloning, functional expression and localization. FEBS Letters 1994; 341:33-8.

[3] Fukuda K, Kato S, Mori K, et al. cDNA cloning and regional distaaribution of a novel member of the opioid receptor family. FEBS Letters 1994; 343:42-6.

[4] Chen Y, Fan Y, Liu J, et al. Molecular cloning, tissue distribution and chromosomal localization of a novel member of the opioid receptor gene family. FEBS Letters 1994; 347:279-83.

[5] Bunzow JR, Saez C, Mortrud M, et al. Molecular cloning and tissue distribution of a putative member of the rat opioid receptor gene family that is not a $\mu, \delta$ or $\kappa$ opioid receptor type. FEBS Letters 1994; 347:284-8.

[6] Wang JB, Johnson PS, Imai Y. DNA cloning of an orphan opiate receptor gene family member and its splice variant. FEBS Letters 1994; 348:75-9.

[7] Wick M J, Minnerah SR, Lin X, Elde R, Law PY and Loh HH. Isolation of a novel cDNA encoding a putative membrane receptor with high homology to the cloned $\mu, \delta$ and $\kappa$ opioid receptors Mol Brain Res 1994; 27:37-44.

[8] Lachowicz JE, Shen Y, Monsma F J, Jr, and Sibley DR. Molecular cloning of a novel G proteincoupled receptor related to the opioid receptor family. J Neurochem 1995; 64:34-40.

[9] Meunier JC, Mollereau C, Toll L. Isolation and structure of the endogenous agonist of opioid receptor-like $\mathrm{ORL}_{1}$ receptor. Nature 1995; 377:532-5.

[10] Reinscheid R, Nothacker HP, Bourson A, et al. Orphanin FQ: a neuropeptide that activates an opioid-like G protein-coupled receptor. Science 1995; 270:792-4.

[11] Cheng Z, Fan GH, Zhao J, et al. Endogenous opioid receptor-like receptor in human neuroblastoma SK-N-SH cell: activation of inhibitory G protein and homologous desensitization. Neuroreport. 1997; 8:1913-8.

[12] Connor M, Yeo A, Henderson G. The effect of nociceptin on $\mathrm{Ca}^{2+}$ channel current and intracellular $\mathrm{Ca}^{2+}$ in the SH-SY5Y human neuroblastoma cell line. Br J Pharmacol 1996; 118:205-7.

[13] Ma L, Cheng Z, Fan GH, Cai YC, Jiang LZ, Pei G. Functional expression, activation and desensitization of opioid receptor-like receptor $\mathrm{ORL}_{1}$ in neuroblastoma $\times$ glioma NG 108-15 hybrid cells. FEBS letter 1997; 403:91-4.

[14] Vaughan CW, and Christie MJ. Increase by the $\mathrm{ORL}_{1}$ receptor (opioid receptor- like 1) ligand, nociceptin, of inwardly rectifying $\mathrm{K}$ conductance in dorsal raphe nucleus neurones. Brit $\mathrm{J}$ Pharmacol. 1996; 117:1609-11.

[15] Mogil JS, Grisel JE, Zhangs G, Belknap JK, Grandy DK. Functional antagonism of $\mu$, $\delta, \kappa$ opioid antinociception by orphanin FQ. Neurosci-Lett 1996; 214:131-4.

[16] Rossi GC, Leventhal L, Pasternak GW. Naloxone sensitive orphanin FQ-induced analgesia in mice. Eur-J-Pharmacol 1996; 12:311, R7-8.

[17] Nishi M, Houtani T, Noda Y, et al. Unrestrained nociceptive response and disregulation of hearing ability in mice lacking the nociceptin/orphanin FQ receptor. EMBO J 1997; 16:185864.

[18] Wu YL, Pu L, Ling K. et al. Molecular characterization and functional expression of opioid receptor-like1 receptor. Cell Research 1997; 7:69-77.

[19] Church and Gilbert. Genomic sequencing. Proc Natl Acad Sci USA 1984; 81:1991-5.

[20] Tian WN, Duzic E, Lanier SM, and Deth RC. Determinants of a 2-adrenergic Receptor Activation of G Proteins: Evidence for a Precoupled Receptor/G Protein State Mol Pharmacol 1993; 45:524.

[21] Anton B, Fein J, To T, Li X, Silberstein L, and Evens C. Immunohistochemical localization of $\mathrm{ORL}_{1}$ in the central nervous system of the rat. J Comp Neurol 1996; 368:229-51.

[22] Houtani T, Nishi M, Takeshima H, Nukada T, and Sugimoto T. Structure and regional distribution of nociceptin/orphanin FQ precursor. Biochem Biophys Res Comm 1996; 219:714-9. 
[23] Saito Y, Maruyama K, Kawano H, et al. Molecular cloning and characterization of a novel form of neuropeptide gene as a developmentally regulated molecule. J Biol Chem 1996; 271:15615-22.

[24] Nothacker HP, Reinscheid RK, Mansour A. Primary structure and tissue distribution of the prphanin FQ precursor. Proc Natl Acad Sci USA 1996; 93:8677-82.

[25] Tian BM, Broxmeyer HE, Fan Y. Altered hematopoiesis, behavior, and sexual function in $\mu$ opioid receptor-deficient mice. J Exp Med 1997; 185:11517-22.

[26] Dooley CT, Houghten RA. Orphanin FQ: receptor binding analog structure activity relationships in rat brain. Life-Sci 1996; 59:PL23-9.

[27] Traynor JR, Nahouaki SR. Modulation by $\mu$-opioid agonists of guanosine- 5-O-3(3- $\left[{ }^{35} \mathrm{~S}\right]$ thio) triphosphate binding to membranes from human neuroblastoma SH-SY5Y cells. Mol Pharmacol 1995; 47:848.

[28] Hilf G, Gierschik P, Jakobs KH. Muscarinic acetylcholine receptor-binding of 5- O-(3-thiotriphosphate) to guanine nucleotide binding proteins in cardiacmembranes. Eur J Biochem 1989; 186:725-31.

[29] Lazareno S, Farries T, Birdsall NJM. Pharmacological characterization of guanine nucleotide exchange reactions in membranes from CHO cells stably transfected human muscarinic receptors m1-m4. Life Sci 1993; 52:449-56.

Received 24-9-1997. $\quad$ Revised 24-10-1997. Accepted 5-11-1997. 